\title{
当科における耳鳴症例の検討
}

\author{
本田学・大河内 幸男・大谷筒
}

\section{A Glinical Study of Patients with Tinnitus}

\author{
Manabu Honda, Yukio Ohkouchi and Iwao Ohtani
}

(Fukushima Medical College)

\begin{abstract}
Patients with tinnitus were analyzed by the standard test of tinnitus. Most of the patients were in their 40's and came to our clinic within 6 months after the onset of the disease. Many of the patients reported nearin a high-pitched tone. Multiple kinds of tinnitus were found 38\% (49/155) of the patients.
\end{abstract}

Key words: tinnitus, standard test, clinical study

\section{はじめに}

耳鳴患者の訴えは種々様々で, それらを的確 に把握するためには，耳鳴検相が必要である. しかし各々の施設では独自の耳鳴検查を行って いたため，施設間の比較検傠が難しかった。 そ のため耳鳴研究会では統一した検査法として, 標準耳鳴検查法 $1984^{11}$ を決め，耳鳴の一般的な 検索の方法について示した。今回ての標準耳鳴 検査法1984年にもとづき，当科における耳鳴症 例について検討を行ってみたので報告する.

\section{対象及び方法}

対象は，炤和 58年から炤和 60 年までに耳鳴 検查を行った，男性 79 人，女性 76 人，計 155 人 である.なお伝音難衲の認められる症例は，今 回の検討から除外した。通常の問診, 恥力検査 などを行いながら，耳鳴の問診表を用い，耳鳴 の訴えや耳鳴の性状及び耳鳴の表現について 記載した。耳鳴の夙波数の検查については, pitch match testにて行った。なお標準耳鳴
検査を行う前の症例については, 標準耳鳴検查 にあとづき処理を行った。

\section{結 果}

年榆構成は（図 1 ）6藏から86歳まで広く分 们しているが，50～60歳台に多く，平均52歳で あった。このうち無難聴性耳鳴は20～30歳台に 多くなっていた。鵈が始まってから初診まで の期間は (表 1 )， 1 力月以内が43例， $1 \sim 6$ 力月が 42 例, 6 力月〜 1 年が 19 例， $1 \sim 5$ 年が 32例, 5 年以上が19例であった。

耳鳴周波数については（図 2), 無難㯖性耳 鳴例 (正:常) は, 高音域之低音域に耳鳴周波数 が 2 つに分か机てみられた。 $\mathrm{c}^{5}$ dip 症例 $\left(\mathrm{c}^{5}\right.$ dip）は， $4 \sim 8 \mathrm{kHz}$ にみれ，㠺に $6 \sim 8$ $\mathrm{kHz}$ と $\mathrm{c}^{5}$ よりやや高音域にずれる例が多くみ られた. 㔖発難揌症例（咨発難恥）は, 高音域 と低音域に分敀してみられた。 その他の感音難 㢷将:例（その他）は，一定の傾问は認められな かったが，高音部に耳鳴凮波数が多くなってい 
た.

耳鳴側及び耳鳴の種類については（表 2), 雨側性耳鳴上顡鳴を訴える例では，48例ゆ24 例， $50 \%$ に 2 種以上の四鳴があると答えてお り，一側性耳鳴においても，107例い35例，33 \%に 2 種以上の耳鳴があると答えていた。なお 笑発難德や $\mathrm{c}^{5} \operatorname{dip}$ では, 多くの例で，上鳴は 1 種類と答えていた。

耳鳴の表現については（表 3 ），キーンが最 屯多く，78例（50.3\%）上半数古好ていた。 次いでジーが51例（32.9\%）であり，あとは少 なくなり，シーン 16 例 $(10.3 \%) ，$ シー15例

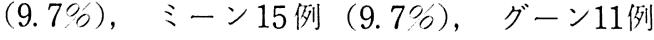
(7.1\%)，ゴウゴウ 10 例 $(6.5 \%)$ の順でみら

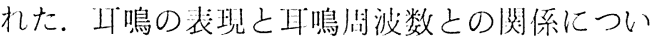
ては，はっきりした倾们が垫められなかった。

丩鳴の大きさ，拈続㧍よび父になりかたにつ いては（表 4)，上鳴の人きさ及び㧠続のとこ ろでは，4点上2点の浙に派えが集的してい た。田鳴の大きさについては，洞常に比へ，感

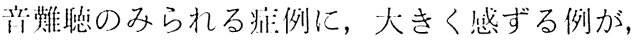

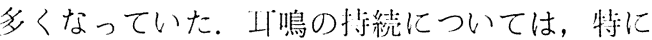
条々に澎められなかった。目鳴の気になり かたについては，感音難䗐の为例で，ひどく感
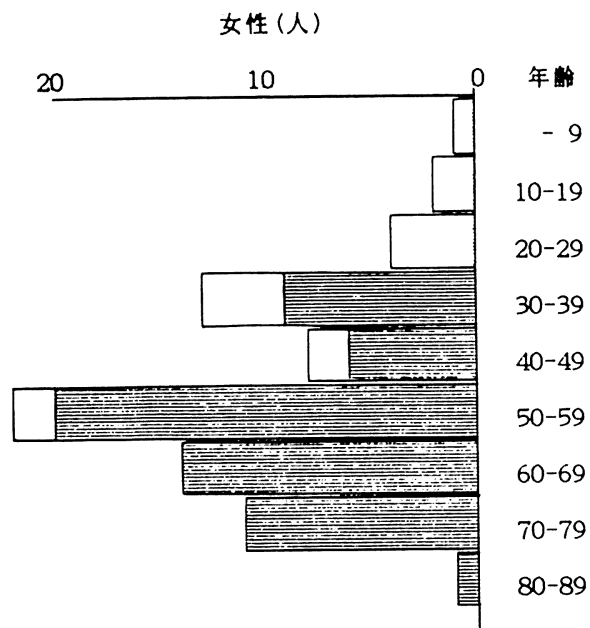

男性 (人)

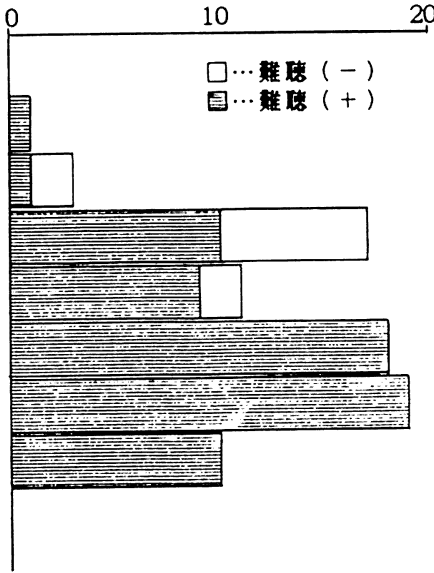

図１作㢼，性别の棈成

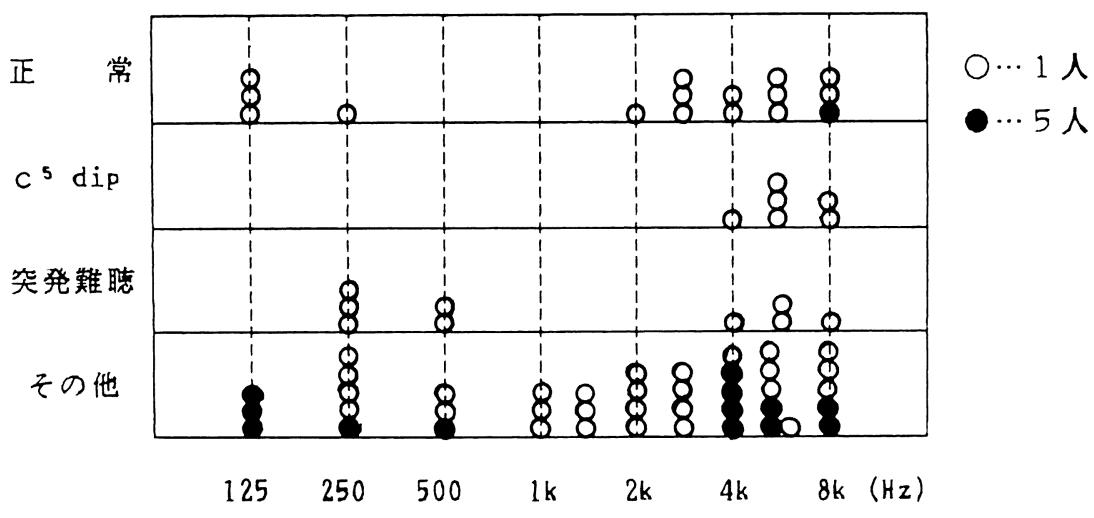

図 2 耳盷鼎波数の分优 
ずる例が多くなっていた。

\section{考察}

Fowler $^{3)}$ は中年以降には85\%耳鳴があると しており，耳鳴は，耳科的矣患の中で屯最もポ ピュラーな瓷患の 1 つである。しかし目覚的な 訴えが主となるため，診断や治療に苦虑する場 合む多い，そのため各々の施設では，独自の耳 鳴検査法を作り，検査をしていたが，内容の違 いから，他の施設との比較が難しかった。そこ

表। 受診までの期間

\begin{tabular}{|c|c|c|c|c|c|c|}
\hline 期 & 間 & 正常 & $\begin{array}{l}\mathrm{c}^{5} \\
\text { dip }\end{array}$ & 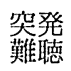 & その他 & 計 \\
\hline \multicolumn{2}{|c|}{ 一ヶ月以内 } & 9 & 1 & 7 & 26 & 43 \\
\hline \multicolumn{2}{|c|}{ 〜 6ヶ月 } & 8 & 0 & 2 & 32 & 42 \\
\hline \multicolumn{2}{|c|}{ ～1 年 } & 3 & 3 & 0 & 13 & 19 \\
\hline \multirow{2}{*}{\multicolumn{2}{|c|}{$\begin{aligned} \sim 5 & \text { 年 } \\
5 & \text { 年以上 }\end{aligned}$}} & 5 & 4 & 1 & 22 & 32 \\
\hline & & 1 & 0 & 0 & 18 & 19 \\
\hline & 計 & 26 & 8 & 10 & 111 & 155 \\
\hline
\end{tabular}

表 2 耳鳴側と耳鳴の種類

\begin{tabular}{|c|c|c|c|c|}
\hline 耳鳴の種類 & 一種 & 二種 & $\begin{array}{l}\text { 三種 } \\
\text { 作 }\end{array}$ & 計 \\
\hline 一側性耳鳴 & 72 & 28 & 7 & 107 \\
\hline 両側性耳鳴 & 14 & 13 & 3 & 30 \\
\hline 頭览 & 10 & 2 & 6 & 18 \\
\hline 計 & 96 & 43 & 16 & 155 \\
\hline
\end{tabular}

表 3 耳鳴の表現（上位 7 例の表現例）

\begin{tabular}{l|r|r|r|r|r}
\hline \hline 耳鳴の表現 & 正常 & $\begin{array}{c}\mathrm{c}^{5} \\
\text { dip }\end{array}$ & $\begin{array}{l}\text { 突登 } \\
\text { 難聴 }\end{array}$ & その他 & 計 \\
\hline キーン & 13 & 5 & 5 & 55 & 78 \\
ジー & 11 & 1 & 0 & 39 & 51 \\
シーン & 2 & 1 & 0 & 13 & 16 \\
シー & 4 & 2 & 2 & 7 & 15 \\
シーン & 2 & 0 & 0 & 13 & 15 \\
グーン & 3 & 1 & 1 & 3 & 11 \\
ゴウゴウ & 2 & 0 & 0 & 8 & 10 \\
& & & & &
\end{tabular}

で，耳鳴研労会では，標準的な検查法の一つと して，標準耳鳴検查法1984を決めた。今回，乙 の敕準耳鳴検查法にもとづき，われわれの耳鳴 症例について検討を加えてみた。

年秢構成については，50歳台に多くなってお り，他の報告4) と同様であり，性別について 屯，男性79例 (51\%)，女性76例 (49\%) と他の 報告(6) と同様に性差は認められなかった。受 診までの期間については, 突発難聴のように, 急に発症した耳鳴は，早期に来科しているが， 他の䅉例も半数以上は 6 力月以内に来科してい た。しかし，その他の感音難聴群では， 5 年以 上之長期の例が18例（16\%）と比較的多くなっ ていた.

耳鳴周波数については，無難㴔性耳鳴は，他 の報告45) と同様に高音域に多く見られたが， 朝隈 ${ }^{8)}$ の報告にあるように，低音域にも認め られ，耳鳴の性質に差がある可能性を示してい る. $\mathrm{c}^{5} \operatorname{dip}$ 例は，障害周波数と考えられる 4 $\mathrm{kHz}$ よりやや高音域の $6 \sim 8 \mathrm{kHz}$ にずれる例

表 4 耳鳴の大きさ，持続，気になり方の程度

\begin{tabular}{|c|c|c|c|c|c|c|c|}
\hline \multicolumn{3}{|c|}{ 耳鳴の程度 } & 正常 & $\begin{array}{l}c^{5} \\
\text { dip }\end{array}$ & 突発 & その他 & 計 \\
\hline \multirow[t]{2}{*}{ 大 } & 4 & 大 & 6 & 5 & 4 & 40 & 55 \\
\hline & 3 & $\uparrow$ & 1 & 0 & 0 & 6 & 7 \\
\hline \multirow[t]{2}{*}{ き } & 2 & & 18 & 3 & 6 & 64 & 91 \\
\hline & 1 & $\downarrow$ & 1 & 0 & 0 & 1 & 2 \\
\hline さ & 0 & 小 & 0 & 0 & 0 & 0 & 0 \\
\hline \multirow[t]{4}{*}{ 持 } & 4 & & 16 & 6 & 8 & 66 & 96 \\
\hline & 3 & $\uparrow$ & 1 & 0 & 1 & 3 & 5 \\
\hline & 2 & & 9 & 2 & 1 & 39 & 51 \\
\hline & 1 & $\downarrow$ & 0 & 0 & 0 & 2 & 2 \\
\hline 続 & 0 & 短 & 0 & 0 & 0 & 1 & 1 \\
\hline 気 & 4 & 重 & 3 & 2 & 2 & 30 & 37 \\
\hline K & 3 & $\uparrow$ & 9 & 2 & 3 & 39 & 53 \\
\hline な & 2 & & 12 & 3 & 4 & 35 & 54 \\
\hline$\eta$ & & $\downarrow$ & 1 & 1 & 1 & 7 & 10 \\
\hline 方 & 0 & 軽 & 1 & 0 & 0 & 0 & 1 \\
\hline
\end{tabular}


が多くみられた。これは dip が正確には $\mathrm{c}^{5}$ の位置よりずれているとか, 耳鳴は傷害部より ややずれた位置に出現するなどのことが考えら れ，なお検討が必要である，笑発難揌症は，恥 力障害の型及び程度に差があるためか, 高音域 と低音域に分散してみられた。まだ症例が少な いため, 今後症例を増やし, 検討する必要があ る. その他の感音難聴症例は, 様々な難聆像を 示すため, 一定の傾向は認められなかったが, 老人性難聴のような，高音障害型の症例が多い ためか，高音部に耳鳴周波数が多くなってい た。

耳鳴側及び耳鳴の種類については, 両側性耳 鳴や頭鳴を訴える例では， $50 \%$ 亿 種以上の耳 鳴があり, 一側性耳鳴においても，33\%に2 種 以上の耳鳴が有り，全体では $38 \%$ に複数の耳鳴 を訴えていた，乙れは，耳鳴検相において，常 に複数の耳鳴を考慮に入れ，よ゙の耳鳴を訴えて いるのかを注意しながら，検查を進めなければ ならない。

耳鳴の表現については，キーンが最む多く, 次いでジーであり，あとは少なくなっていた。 キーン, ジーなどの一般的な表現に偏り, 耳鳴 検査の表現例 して示されている他の多くは当 てはまらないてとが多く，表現例については， まだ，検討の余地があると考えられる，耳鳴の 表現と耳鳴周波数との関係については，はっき りした傾向は認められなかった。

耳鳴の大きさ，持続については，特に咨患別 に差は認められなかった。しかしその程度の点 数では， 4 点と 2 点の所に訴えが集中してい た。これは，耳鳴の気になりかたの項目に比 へ，前の 2 つ項目はやや具体性に次けるため, 記載に偏りが出たと考えられる。耳鳴の大きさ については，感音難聴のある例が，大きく感ず る場合が多い結果であった。

\section{まとめ}

耳鳴患者 155 例について橧淮耳鳴検査1984に あとづき，検㗅を行ってみたので報告した。

1. 耳鳴患者は，50蔵代に多く，性差はなか った，受診までの則間は，6力月以内が多かっ た。

2.耳鳴の周波数については，高音域に多く みられた。

3. 耳鳴側及び耳鳴の種類については，38\% （49/155）の例で複数の耳鳴を訴えていた.

4. 耳鳴の表現については，一般的な表現に 偏りはっきりした側向は認められなかった。

5. 耳鳴の持続については，特に聅患别に差 は認められなかった，耳鳴の大きさ，気になり かたについては，感音難揌例で，ひよ゙く感ずる 例が多かった。

\section{参考文献}

1 ) 耳鳴研究会 : 標準耳鳴検査法1984. 耳鳴研究会, 1984.

2) 本田 学, 他: 当科における耳鳴の調查. Audiology Japan $26: 575 \sim 576,1983$.

3) Fowler EP : Nonvibratory tinnitus: Factors underlying subaudible and audible irritations. Arch Otolaryng $47: 29 \sim 36,1948$.

4) 大内利明，他：バランス法による耳鳴の評価. Audiology Japan 26:105〜111, 1983.

5 ) 矢風崎恵美子, 他 : 当病院における耳鳴患者の実 態. Audiology Japan 26:138〜141, 1983.

6 ) 鳥山稔, 他: 耳鳴の臨床的砳労. Audiology Japan $27: 469 \sim 470,1984$.

7 ) 藤田和寿, 他：オージオグラムによる耳鳴患者の 検討. Audiology Japan 28:567〜568, 1985.

8 ）朝猿慎一郎, 他：無難聴性耳鳴と無響室性耳鳴に ついて. Audiology Japan 26:581〜582, 1983.

別刷請求先：本田 学

T960 福島市杉妻町 4-45

福島県立医科大学耳鼻咽喉科学教室 